\title{
Shoreline Change, Seawalls, and Coastal Property Values
}

\author{
Di Jin*, Porter Hoagland, Donna K. Au, Jun Qiu \\ Marine Policy Center \\ Woods Hole Oceanographic Institution \\ Woods Hole, MA 02543
}

* Corresponding author Eamil: djin@whoi.edu Phone: 1-508-289-2874

June 16, 2015

\section{Acknowledgements}

This article was prepared under award number NA10OAR4170083 (WHOI Sea Grant Omnibus) from the US Department of Commerce, National Oceanic and Atmospheric Administration (Northeast Regional Sea Grant Consortium project 2014-R/P-NERR-14-1-REG); award number GEO-0815875 from the US National Science Foundation (Dynamics of Coupled Natural and Human Systems [CNH]); award number NSF/OCE 1325430 from the US National Science Foundation; and with support from the J. Seward Johnson Fund in Support of the Marine Policy Center and the John E. Sawyer Endowed Fund. 


\title{
Shoreline Change, Seawalls, and Coastal Property Values
}

\begin{abstract}
We investigate the effects of shoreline change and protective structures (seawalls) on home values, using data on residences sold between 2000 and 2010 in the coastal towns of Marshfield, Duxbury, and Plymouth, Massachusetts. These towns comprise shorelines that exhibit moderate rates of shoreline change, relative to other shorelines in the state, with extensive armoring. We investigate explicitly the effects of hard structural protection in combination with environmental amenities and hazards (distance to a beach, elevation of a property, location in a flood zone). We find that homeowners pay a premium in housing markets for nearshore properties protected by nature (higher elevations or more stable shorelines) or by humans (seawalls). The average marginal increase in nearshore property values associated with a $1 \mathrm{~m}$ rise in elevation is 2 percent, a $1 \mathrm{~m}$ (horizontal distance) decrease in the erosion rate is 0.2 percent, and location behind a seawall is 10 percent. The effects of erosion, elevation, and seawalls appear to be limited to properties located in close proximity to water or to oceanfront residences. Overall, the benefits of access to ocean amenities dominate the risks of exposures to hazards associated with shoreline change.
\end{abstract}




\section{Introduction}

Worldwide, coastal communities face threats of shoreline change. Exacerbated by a warming climate, rising sea levels have resulted in the permanent inundation of residences and businesses and the increased risks of flooding during storms (Donnelly et al. 2004; Titus et al. 2009; Aerts et al. 2014). It has been estimated that 25 percent of residences within 150 meters of the shoreline may be affected by erosion-related property losses over the next 50 years (THC 2000).

The economic effects of shoreline change, of particular interest to those owning property near the waterfront, now is gaining momentum as an area of research relevant to questions of coastal vulnerability, resilience, and adaptation to future changes. More importantly, it carries significance from a community perspective. As discussed in Kriesel et al. (2000), coastal communities must consider whether to leave the shoreline alone, implying a more rapid retreat from the coast, to replenish eroded beach materials, or to stabilize the shoreline with "hard" structures (e.g., seawalls or revetments). Many of these decisions involve cost-benefit assessment. While the costs of coastal protection (e.g., beach nourishment or seawall construction) are typically straightforward to calculate, associated benefits are often difficult gauge. Thus, estimating the benefits of coastal protection has been an important of area of research in many coastal communities.

Hedonic pricing models have been widely used to estimate benefits of ecosystem services (e.g., coastal amenity and recreational values) around the world (Brown and Pollakowski 1977; Edwards and Gable 1991; Hamilton 2007; Dantas et al. 2010) and, in a smaller number of studies, to evaluate coastal hazards (e.g., flood and erosion) (Landry et al. 2003; Samarasinghe and Sharp 2010; Atreya and Czajkowski 2014). The basic idea of the hedonic pricing model is 
that property values can be affected by environmental characteristics in ways similar to structural characteristics (Freeman 1979). Table 1 summarizes the variables included in hedonic pricing models investigating coastal amenities and flood risks, and their impacts on property values. Generally, home buyers are willing to pay a premium for living near the water. Property values are negatively related to distance from the coastline, and this relationship is a nonlinear one in the sense that the coastal premium is significantly greater at the waterfront. Both a water view and a wide beach have positive impacts on property values.

Because the most desirable homes in terms of coastal amenities are located typically at places with higher flood risks due to their proximity to the water, the effects of the inclusion of flood risk variables in hedonic models has not been clear-cut. For example, while Samarasinghe and Sharp (2010) identified the negative impacts of flood risks, Atreya and Czajkowski (2014) found that amenity effects dominated home values. Bin et al. (2008) showed that a threedimensional measure of ocean view accounting for natural topography could be used to isolate risk factors from spatial amenities. The elevation variable was insignificant in the model of Bin et al. (2011), and those authors explained that lower elevations were likely to provide easier access to coastal amenities, yet at the same time higher vulnerability to storm surge flooding or shoreline erosion. The benefits associated with seawalls have been detected among homes directly protected by them. For both tourists and non-waterfront residents, seawalls have a negative impact on coastal amenities (Kreisel and Friedman 2002; Hamilton 2007). Although results of these studies have provided essential information for coastal decision-makers as they undertake analyses of the net benefits of beach nourishment, land use zoning, or climate change adaptation, an important fact is that hedonic pricing models are location-specific due to 
variations in local socioeconomic and environmental conditions. If local conditions are not similar, parameter estimates from a region do not appear to be transferable to other areas.

The Massachusetts coastline exhibits characteristics that differ from the broad barrier shorelines of the mid- and south Atlantic coasts, and it has been largely ignored by earlier national studies of erosion and sea-level rise impacts ( $c f$. , Yohe et al. 1996 [these authors do include Westport, Massachusetts on the coast of Buzzards Bay]; Kriesel et al. 2000). Typical coastal geology comprises narrow, steep beach faces made up of coarse materials, occasional rock outcroppings, extensive scarps, and dune systems, especially on Cape Cod. Further, a significant portion of the coast has been protected by seawalls and revetments (EEA 2014a). While examples of beach replenishment projects exist, these are not as common as they are for the beaches on the mid- and south Atlantic or Gulf of Mexico coasts. In many areas, the bottling up of erodible material behind structures contributes to an acceleration of coastal erosion in downdrift, unstructured locations and to chronic and costly problems involving the maintenance and repair of seawalls, particularly subsequent to northeast storm events.

In many cases, seawalls are old, ill-maintained, and erosion has removed even a vestigial beach, thereby increasing their vulnerability to storm surges and wave action. In August 2014, the Massachusetts legislature authorized the floating of a $\$ 2.2$ billion "environmental" bond to fund land and water conservation, water and wastewater infrastructure, and clean energy and energy efficiency programs. $\$ 120$ million of this bond would be directed at investments in “critical coastal infrastructure," including seawalls. There is an urgent need to develop necessary economic parameters for conducting cost-benefit analysis of both short- and long-run coastal protection measures in the region. 
Massachusetts (and Maine, until 1820 a part of Massachusetts) represents a unique example of coastal policy because private ownership typically extends to the mean low water line, in contrast to other coastal states. Areas do exist where the public has limited access to beaches, such as those located on very high energy coastal barriers, and especially in reserved areas such as the Cape Cod National Seashore and the Plum Island National Wildlife Refuge. Although exceptions do exist, in the residentially developed areas, those coastal property owners not located on the immediate shorefront may be restricted in the extent to which they can benefit from recreational activities on proximate beaches. As a consequence, in these cases, the benefits of non-waterfront coastal property ownership may be limited to aesthetic views.

The objectives of this study are to develop a hedonic pricing model to evaluate the economic effects of shoreline change and hard structural protection in coastal New England and to estimate essential parameters (e.g., benefits of seawall protection) that are crucial for evaluating climate change response strategies in this region. When presented with erosioncreated hazards, people who live on or near the shoreline can choose either to protect their properties (via seawalls, beach replenishment, etc.) or to relocate further away from the coast. Economic theory suggests that individuals would tend to choose the option that minimizes total costs. While the benefits of living near the coast are on display through observations of the premiums attached to the prices of waterfront properties, we seek to control for these premiums, thereby focusing on assessing the risks of living near a dynamic coast that responds both to short term storm events as well as longer term sea-level rise.

In addition to the standard environmental predictors $(e . g$. , distance to beach, topographical elevation, and location in a flood zone), we investigate explicitly the effects of hard structural protection (seawalls) on property values. The coefficients of these environmental 
variables in a hedonic model reflect the marginal implicit prices that homeowners are willing to pay to reduce the exposure of their properties to inundation or erosion risks (Smith 1985). Results of our research may provide information for community decisions of whether or not to invest in coastal protection measures, thereby contributing to discussions about choices among adaptive strategies to climate change.

Our work extends earlier analyses of coastal towns in Massachusetts (Eberbach and Hoagland 2011; Au 2011). We focus on three towns, Marshfield, Duxbury, and Plymouth, located along the shoreline south of Boston (the "South Shore" region; Fig. 1). The three towns were selected for their socioeconomic and natural features, representative of coastal Massachusetts. The South Shore is composed of a mix of mid-sized cities, suburban towns, and rural towns. Massachusetts Route 3, also known as the "Pilgrim Highway," connects the three coastal towns with Boston where the region's major airport (Logan International) and train station (South Station) are located. Duxbury has the highest median household income, followed by Marshfield and Plymouth (Table 2).

The South Shore is characterized by moderate shoreline change, primarily residential development of variable density in both coastal barrier and backbay estuarine environments, and significant anthropogenic shoreline protection in the form of seawalls or revetments (Fig., 2; EEA 2014). Most residential houses are one- to two-story wooden structures with shingle exteriors built on concrete foundations (i.e., Colonial, Cape Cod, or Ranch style houses).

\section{Methods and Data}

According to Freeman (1979), most of the characteristics that explain property values (so-called "hedonic" prices) fall into structural, neighborhood, or environmental categories. A 
hedonic pricing model typically is formulated as:

$$
\ln P_{i}=\beta_{0}+\beta_{1} S_{i}+\beta_{2} N_{i}+\beta_{3} E_{i}+\beta_{4} T_{i}+\varepsilon_{i}
$$

where $P_{i}$ is the sale price of property $i$, which is affected by its structural characteristics $\left(S_{i}\right)$, neighborhood $\left(N_{i}\right)$, environmental characteristics $\left(E_{i}\right)$, and time of sale $\left(T_{i}\right) . \beta \mathrm{s}$ are coefficients to be estimated, and $\varepsilon$ is a random error term. For the above semi-log function, the regression coefficient $(\beta)$ on each independent variable can be interpreted as the average percentage increase in property value associated with one unit increase in the independent variable.

The structural variables used in the study include lot size, living area, total rooms, number of bathrooms, number of bedrooms, the age of the house when it was sold, and building style. It is expected that lot size, living area, and number of bathrooms will have a positive effect on property values, with diminishing returns to scale. The age of the house when it was sold is expected to have a negative effect on property values; it can be viewed, in some sense, as an annual depreciation rate (Kriesel et al. 2000). The older a property, the greater is the expected amount of money needed to maintain it or fix it up, thus decreasing its value. The neighborhood variables may include the identity of the local municipality, comprising effects such as school quality and income levels.

A number of environmental variables are included to examine the effects on property values of ocean or waterfront amenities (e.g., distance to water), coastal hazards (e.g., erosion and storm damage), and coastal protection measures (e.g., seawalls). We expect that the coefficient on distance to a waterbody would be negative. Properties closer to the shoreline are associated with such amenities as easier and faster access to recreational beach activities and 
perhaps a better ocean view. Homeowners typically pay a premium for proximity to a body of water. While this may be the case, one must also consider potential opposing effects. Properties located farther from an ocean shoreline are likely to be more protected from coastal hazards. The coefficient for a variable that characterizes erosion is expected to be negative, because, ceteris paribus, properties near a shoreline with high erosion rates are expected to be worth less, and shorelines with lower erosion rates or accretion tend to have wider beaches and higher perceived beach quality.

We estimate equation (1) with three different regression models. A generalized linear regression model is used to correct for heteroscedasticity. We employ a White estimator to calculate a consistent standard error (Greene 2012). Because property sales prices in close proximity tend to be related spatially due to neighborhood effects (e.g., location amenities or structural characteristics), we also develop two regression models to address the effects of spatial dependence. A spatial regression model corresponding to (1) is formulated as:

$$
\mathbf{P}=\rho \mathbf{W P}+\beta_{0} \mathbf{i}+\beta_{1} \mathbf{S}+\beta_{2} \mathbf{N}+\beta_{3} \mathbf{E}+\beta_{4} \mathbf{T}+\boldsymbol{\varepsilon}, \text { with } \quad \boldsymbol{\varepsilon}=\lambda \mathbf{W} \boldsymbol{\varepsilon}+\mathbf{u}
$$

where $\mathbf{P}$ is a vector with element $\ln P_{i} ; \mathbf{W}$ is a spatial weights matrix; $\mathbf{i}$ is a vector of ones; and $\mathbf{u}$ a vector of i.i.d. errors. $\rho$ and $\lambda$ are spatial parameters to be estimated. The coefficient $\rho$ measures the extent to which one observation is dependent on its neighbors, and the coefficient $\lambda$ measures the extent to which an error of one observation is associated with the errors of neighboring observations. A spatial regression model typically includes either a spatially lagged dependent variable (WP) ( $c f$. , Morgan and Hamilton 2010) or a spatial autoregressive error term ( $\boldsymbol{\varepsilon})$. A spatial lag model is specified $\rho \neq 0$ and $\lambda=0$, and a spatial error model $\lambda \neq 0$ and $\rho=0$ (Anselin 1988, 2005) 
We compiled home sales data from The Warren Group, a real estate and financial information service data company. The data comprised structural characteristics, spatial locations, and sales prices from 2000 to 2010 for 5,925 residences in the Massachusetts coastal towns of Duxbury, Marshfield, and Plymouth. To focus on single-family residences, properties designated as condominiums, apartments, or multi-family residences were excluded. In order to eliminate "arms-length" sales, all residences with a last sale price of less than $\$ 10,000$ were excluded. Properties with missing information were excluded. The final data set included 3,996 observations.

Data for the environmental variables were obtained from public sources. These data were compiled and merged with the residence sales data using geographical coordinates in ArcGIS. Data on elevations were input into ArcGrid from the US National Map (USGS 2014). Digital shoreline locations, shoreline types, and seawall data sets (shape files) were compiled from the Massachusetts Ocean Resource Information System (MORIS). Digital flood zone maps were downloaded from Federal Emergency Management Agency's (FEMA) Flood Map Service Center.

Descriptive statistics are shown in Table 3. Sales prices in different years were converted to 2013 dollars using the US Consumer Price Index for housing. The average price in the sample was $\$ 451,795$, with prices ranging from $\$ 11,117$ to $\$ 4,929,951$. The average numbers of bedrooms and bathrooms were 3.16 and 1.98, respectively. The average age of residences at the time of sale was 36.8 years.

While the definitions of most variables are straightforward, several environmental variables need further explanation. The landscape in the study area is complex, including both the seacoast and inland waters (ponds or rivers). While ocean and inland waters may provide 
similar amenities and recreational opportunities, ocean waters clearly exhibit some unique features. To separate the effects of the ocean and inland waters on property values, two distance variables are included in the study: one measures the distance from a residence to the nearest waterbody (either ocean or inland) and the other measures the distance to the ocean, using the digital coastline in 1998 . Thus, the two distance variables measure the general proximity to water as well as the specific ocean proximity.

Erosion was calculated as the difference between two measures of distance to the ocean, one based on the coastline in 1998 and another in 2007. A negative value represents accretion. The shoreline type variables are based on the primary classification for each section of the coastline, although each section typically includes more than one type. There are five primary coastline types in the study area: marshes, scarps and steep slopes in sand, solid man-made structures and riprap, mixed sand and gravel beaches, and low banks and tidal flats.

The flood zone variables are based on FEMA's flood zone classification. These zones (A, $\mathrm{AE}, \mathrm{AO}$, and VE) are subject to inundation by the 1-percent-annual-chance flood event. The AE zone is determined by detailed hydraulic analyses, while the A zone is not. The AO zone is subject to sheet flow on a sloping terrain. The VE zone is subject to storm-induced velocity wave action.

\section{Results}

Table 4 summarizes the results of three model estimations. Model I is the GLM estimation of equation (1). Model II is the spatial lag model, and Model III is the spatial error model, both specified in equation (2). 
Focusing initially on the results of Model I, compared with the baseline property values in Marshfield, the property values in Duxbury are, on average, $21.4 \%$ higher and the values in Plymouth 20\% lower. Both lot size and living area have significant and positive effects on property value, with diminishing returns, as indicated by the negative coefficients on the quadratic terms. One additional bathroom, on average, leads to an $8.1 \%$ increase in property value, ceteris paribus. In contrast, the age of the house has small negative effects on its value, $0.4 \%$ lower for every ten years of age. The building style also has a significant effect on property values. Compared with the mostly colonial and Cape Cod style structures in the study area, ranch and cottage residences have lower values, while contemporary residences are $7.4 \%$ more expensive, on average.

Results of the environmental variables suggest that there is a negative relationship between the distance to the ocean and property value. Increased distance to the ocean is likely associated with poorer or nonexistent ocean views. In the three towns, a 1.0\% drop in home value is associated with every $1 \mathrm{~km}$ increase in the distance to the ocean. A similar negative relationship exists between home value and distance to any waterbody, except that the relationship is nonlinear (i.e., the square root of the distance). Thus, with increasing distance from a waterbody, the value of a residence declines rapidly at first, followed by a slower decline.

Significant effects of elevation on property values were detected only for residences that were in close proximity to a waterbody (within $0.05 \mathrm{~km}$ ). Due to the nearness of a waterbody, these properties were relatively more valuable, with values near $\$ 650,000$. Properties that were well elevated above the shoreline also are more protected against floods and storm surges, and they may have better views too. Squared elevation provides a better model fit, such that a property's value rises by $2 \%(\$ 14,000)$ at an elevation of $1 \mathrm{~m}$ and by $4 \%(\$ 29,000)$ at $2 \mathrm{~m}$. 
Likewise, the costs of erosion were detected only in those residences in close proximity to the ocean. The costs of erosion are minor, however. The model estimates a $0.18 \%(\$ 1,176)$ reduction in property value for an annual erosion rate (horizontal loss of shoreline) of $1 \mathrm{~m}$. Many properties in Duxbury and Plymouth are located in backbay environments. It seems likely that homeowners' perceived risk of living near the water may be reduced in the backbay environment due to a natural protection from erosive factors at the shoreline.

The effects of seawalls on property values were most noticeable on residences located in immediate proximity to the ocean. The average value of residences located behind seawalls was $\$ 480,000$. For waterfront residences, if a seawall was present, the average marginal increase in property value was $10 \%(\$ 48,000)$. Among the different shoreline types examined, only mixed sand and gravel beaches resulted in positive and significant effects on home value. The value of a property located in the flood zone (AE) was 6 percent lower than residences outside of the flood zone, ceteris paribus.

The estimated coefficients on the dummies for each sale year of a home indicate that, relative to the base year of 2010, sales prices were lower in 2000 and 2001, higher from 2002 to 2008, with a peak in 2005 (34\% higher). The coefficients on the dummies for sale years 2007 and 2008 clearly showed the economic and housing market downturn of late 2007 and the recession that began in 2008 .

Because property sale prices often are spatially correlated, the hedonic model was reestimated using spatial regressions (Models II and III in Table 4). The estimations were implemented with GeoDa 1.6.0 (2014). Results of robust Lagrange multiplier test statistics suggested that both spatial dependence and spatial error dependence were present, using a spatial weights matrix for second-order rook contiguity. As shown under the heading of Model II, the 
estimated spatial autoregressive coefficient $(\rho)$ is 0.254 and highly significant. The spatial autoregressive coefficient $(\lambda)$ is 0.364 and also highly significant (Model III).

Although there were some minor differences in the magnitude and significance of the regression coefficients among Models I, II, and III, the overall results were quite robust. A noticeable difference is the result for the flood zone variable $\mathrm{AE}$, which was not significant in the spatial models. Thus, the effect of flood zone designation on property values in the study area may not be as robust as other variables.

\section{Discussion}

The results of the analysis with respect to property structural features, such as lot size, living area, and age of the house, are consistent with those in the literature (Brown and Pollakowski 1977; Edwards and Gable 1991; Pompe and Rinehart 1994; Kriesel et al. 2000). In terms of environmental variables, our results are in general agreement with those of earlier studies (Table 1). For example, the distance to the ocean is found to be negatively related to property value, as in earlier studies (Brown and Pollakowski 1977; Kriesel et al. 2002 and 2003; Eberbach and Hoagland 2011). The negative coefficient on distance to the ocean is intuitive because of diminished (or nonexistent) ocean views and increased costs of beach access to public beaches. Naturally, this would result in the reduced sale price of a home. In addition, we found that similar effects exist for inland waters, as inland waters offer similar amenities to nearby residences. The study results also show that the rate of erosion has a negative impact on property value (as in Kreisel and Friedman 2002 and 2003; Landry et al. 2003; Eberbach and Hoagland 2011). An increase in the erosion rate of the nearest shoreline should have a negative effect on the sale price of a home because a higher erosion rate may increase the probability of inundation, 
damage, and loss of property in future decades, particularly for oceanfront residences. Further, this study confirms that waterfront property value is positively related to higher elevation (as in Kreisel and Friedman 2002 and 2003) and the presence of seawall protection (as in Atreya and Czajkowski 2014).

Our results differ in several ways with those of earlier studies. First, we did not examine explicitly the effects of the time until inundation, as had been undertaken in other studies (Kriesel et al. 2000). Our study area included a complex and meandering coastline along which both erosion and accretion can occur. It was difficult to estimate the time to inundation for properties located near locations where erosion switches to accretion. We found that the effects of erosion risks on property values tended to be relatively minor and limited to nearshore properties. This result may be the consequence of a number of factors, including the extensive structural protections already in place, the presence of residential developments in naturally protected backbay environments, and the occurrence of material accretion in some limited areas.

Second, we did not find the negative effects of seawalls on non-shorefront properties that had been discovered in other studies (Kriesel and Friedman 2002, 2003). The reason for this result may be that, in Massachusetts, coastal waterfront properties extend to the mean low water line, limiting recreational benefits to waterfront property owners. As a consequence, there are few recreational services to be lost to non-waterfront property owners when a beach erodes in front of a seawall. The main sources of coastal value to the non-waterfront property owners are likely the aesthetic views. These views, to the extent that they exist and are not blocked by the waterfront residences, are mostly unaffected by the construction and maintenance of seawalls.

The degradation of seawalls, particularly during severe northeast storms, has become a chronic problem for coastal communities. In 2013, a special "Dam and Seawall Repair and 
Removal Fund" was established to identify and fund priority projects, and a recently passed environmental bond would expand the Fund's capital reserves. Recent examples of applications of this Fund to the Massachusetts South Shore include the \$2.75 million Stoney Beach Seawall Reconstruction in Hull and the $\$ 0.5$ million Hewitt's Point Seawall-Revetment in the Brant Rock section of Marshfield (EEA 2014b). The results of our research imply that, because nearshore property owners are the main beneficiaries of seawalls, these owners could be assessed a levy to cover, at a minimum, the pro-rated principal and interest payments on and the costs of administering the bond issue. In the future, these same owners could be taxed directly to cover the costs of ongoing maintenance and even new construction. Such a policy would ensure that those who benefit the most from residing in a coastal location also bear the associated risks of shoreline change (Parsons and Noailly 2004).

To improve our understanding of the benefits associated with different coastal protection options, it is important to disentangle the effects of coastal amenities and hazards on property values. At present, data used for coastal hazard characterization, such as erosion and elevation, are either imprecise or incorrect. In addition, as Landry and Hindsley (2011) have noted, significant error may exist in measuring coastal erosion due to dynamic interactions between natural erosion and beach nourishment. Thus, future improvements to the hedonic modeling of coastal hazards will need to depend on improvements in our understanding of coastal geodynamic processes and in coastal mapping (Bin et al. 2008)

\section{Conclusion}

Hedonic models have been estimated to determine how housing characteristics, neighborhoods, and associated environmental characteristics contribute to property values in the 
towns of Duxbury, Marshfield, and Plymouth, Massachusetts. Results of the study provide quantitative estimates on the economic effects of shoreline change and hard structural protection in coastal New England. The average marginal increase in nearshore property values associated with a $1 \mathrm{~m}$ rise in elevation is 2 percent, a $1 \mathrm{~m}$ (horizontal distance) decrease in the erosion rate is 0.2 percent, and location behind a seawall is 10 percent. The effects of erosion, elevation, and seawalls appear to be limited to properties located in close proximity to water or to oceanfront residences. These estimates are essential for developing cost-benefit analyses of shoreline protection measures and climate change response strategies in the study region. 


\section{References}

Atreya A, Czajkowski J. 2014. Housing Price Response to the Interaction of Positive Coastal Amenities and Negative Flood Risks. Working Paper \# 2014-09. Risk Management and Decision Processes Center, The Wharton School, University of Pennsylvania.

Anselin L. 1988. Spatial Econometrics: Methods and Models. Kluwer Academic Publishers, Dordrecht, The Netherlands.

Anselin L. 2005. Exploring Spatial Data with GeoDa: A Workbook. Urbana, IL: Spatial Analysis Laboratory, Department of Geography, University of Illinois at Urbana-Champaign (March 6).

Au DK. 2011. The Economic Effects of Shoreline Change on Housing Prices in Coastal Massachusetts. M.S. Thesis. Medford, MA: Department of Economics, Tufts University.

Bin, O, Crawford TW, Kruse JB, Landry CE. 2008. Viewscapes and flood hazard: coastal housing market response to amenities and risk. Land Economics 84 (3): 434-448.

Bin O, Poulter B, Dumas CF, Whitehead JC. 2011. Measuring the impact of sea-level rise on coastal real estate: a hedonic property model approach. Journal of Regional Science 51(4):751-767.

Brown GM Jr., Pollakowski HO. 1977. Economic valuation of shoreline. Review of Economics and Statistics 59:272-278.

Conroy SJ, Milosch JL. 2011. An estimation of the coastal premium for residential housing prices in San Diego County. Journal of Real Estate Finance and Economics 42:211-228.

Dantas M, Gaschet F, Pouyanne G. 2010. Regulatory Zoning and Coastal Housing Prices: A Bayesian Hedonic Approach. Working Papers of GREThA, n²010-12. Université Montesquieu Bordeaux IV. 
Donnelly JP, Cleary P, Newby P, Ettinger R. 2004. Coupling instrumental and geological records of sea-level change: Evidence from southern New England of an increase in the rate of sea-level rise in the late 19th century. Geophysical Research Letters 31:L05203.

Eberbach S, Hoagland P. 2011. Estimating the economic effects of shoreline change on assessed property values in Sandwich, Massachusetts. ASCE Conf. Proc. doi:10.1061/ 41185(417)21.

Edwards SF, Gable F. 1991. Estimating the value of beach recreation from property values: an exploration with comparisons to nourishment costs. Ocean \& Shoreline Management 15(1):37-55.

Energy and Environment Administration (EEA). 2014a. Draft Massachusetts Ocean Management Plan (September 2014). Boston: Commonwealth of Massachusetts. Last accessed on October 3, 2014 at: http://www.mass.gov/eea/oceans/ocean-plan/2014-draftocean-plan-v1-text.pdf.

Energy and Environment Administration (EEA). 2014b. Patrick Administration awards $\$ 13.5$ million in dam and seawall grants, loans (January 13, 2014). Boston: Commonwealth of Massachusetts. Last accessed on October 3, 2014 at: http://www.mass.gov/eea/pr2014/dam-seawall.html.

Freeman AM III. 1979. The Benefits of Environmental Improvement: Theory and Practice. Resources for the Future, Washington, DC.

Gopalakrishnan S, Smith MD; Slott JM, Murray AB. 2011. The value of disappearing beaches: a hedonic pricing model with endogenous beach width. Journal of Environmental Economics and Management doi:10.1016/j.jeem.2010.09.003.

Greene WH. 2012. Econometric Analysis. 7th Edition. Prentice Hall, Boston, MA. 
Hamilton JM. 2007. Coastal landscape and the hedonic price of accommodation. Ecological Economics. 62:594-602.

H. John Heinz III Center for Science, Economics, and the Environment (THC). 2000. Evaluation of Erosion Hazards. April, Washington, D.C.

Aerts JCJH, Botzen WJW, Emanuel K, Lin N, de Moel H, Michel-Kerjan EO. 2014. Evaluating flood resilience strategies for coastal megacities. Science 344:473-475.

Kriesel W, Landry C, Keeler A. 2000. Coastal Erosion Hazards: The University of Georgia’s Results. App. D(i) in Evaluation of Erosion Hazards. Washington: H. John Heinz III Center for Science, Economics, and the Environment (April).

Kreisel W, Friedman R. 2002. Coastal hazards and economic externality: implications for beach management policies in the American Southeast. Heinz Center Discussion Paper. Washington: The Heinz Center (May).

Kreisel W, Friedman R. 2003. Coping with coastal erosion-evidence for community-wide impacts. Shore \& Beach 71:19-23.

Landry CE, Allen T. 2014. Hedonic Property Prices and Coastal Beach Width. Department of Agricultural \& Applied Economics, University of Georgia. Available at SSRN: http://ssrn.com/abstract=2474276.

Landry CE, Hindsley P. 2011. Valuing beach quality with hedonic property models. Land Economics 87:92-108.

Landry CE, Keeler AG, Kriesel W. 2003. An economic evaluation of beach erosion management alternatives. Marine Resource Economics 18:105-127. 
Morgan OA, Hamilton SE. 2010. Estimating a payment vehicle for financing nourishment of residential beaches using a spatial-lag hedonic property price model. Coastal Management 38:65-75.

Parsons GR, Noailly J. 2004. A value capture property tax for financing beach nourishment projects: an application to Delaware's ocean beaches. Ocean \& Coastal Management 47:49-61.

Parsons GR, Powell M. 2001. Measuring the cost of beach retreat. Coastal Management 29:91103.

Pompe JJ, Rinehart JR. 1994. Estimating the effect of wider beaches on coastal housing prices. Ocean \& Coastal Management 22:141-152.

Pompe JJ, Rinehart JR. 1999. Establishing fees for beach protection: paying for a public good. Coastal Management 27:57-67.

Samarasinghe O, Sharp B. 2010. Flood prone risk and amenity values: a spatial hedonic analysis. Australian Journal of Agricultural and resource Economics 54:457-475.

Smith K. 1985. Supply uncertainty, option price, and indirect benefit estimation. Land Economics 61:303-307.

Titus JG, Anderson KE, Cahoon DR, Gesch DB, Gill SK, Gutierrez BT, Thieler ER, Williams SJ. 2009. Coastal Sensitivity to Sea-Level Rise: A Focus on the Mid-Atlantic Region. Report by the U.S. Climate Change Science Program and the Subcommittee on Global Change Research. Washington D.C.

Yohe G, Neumann J, Marshall P, Ameden H. 1996. The economic cost of greenhouse-induced sea-level rise for developed property in the United States. Climatic Change 32:387-410. 
Table 1. Variables Measuring Coastal Amenity and Flood Risk in Hedonic Pricing Models

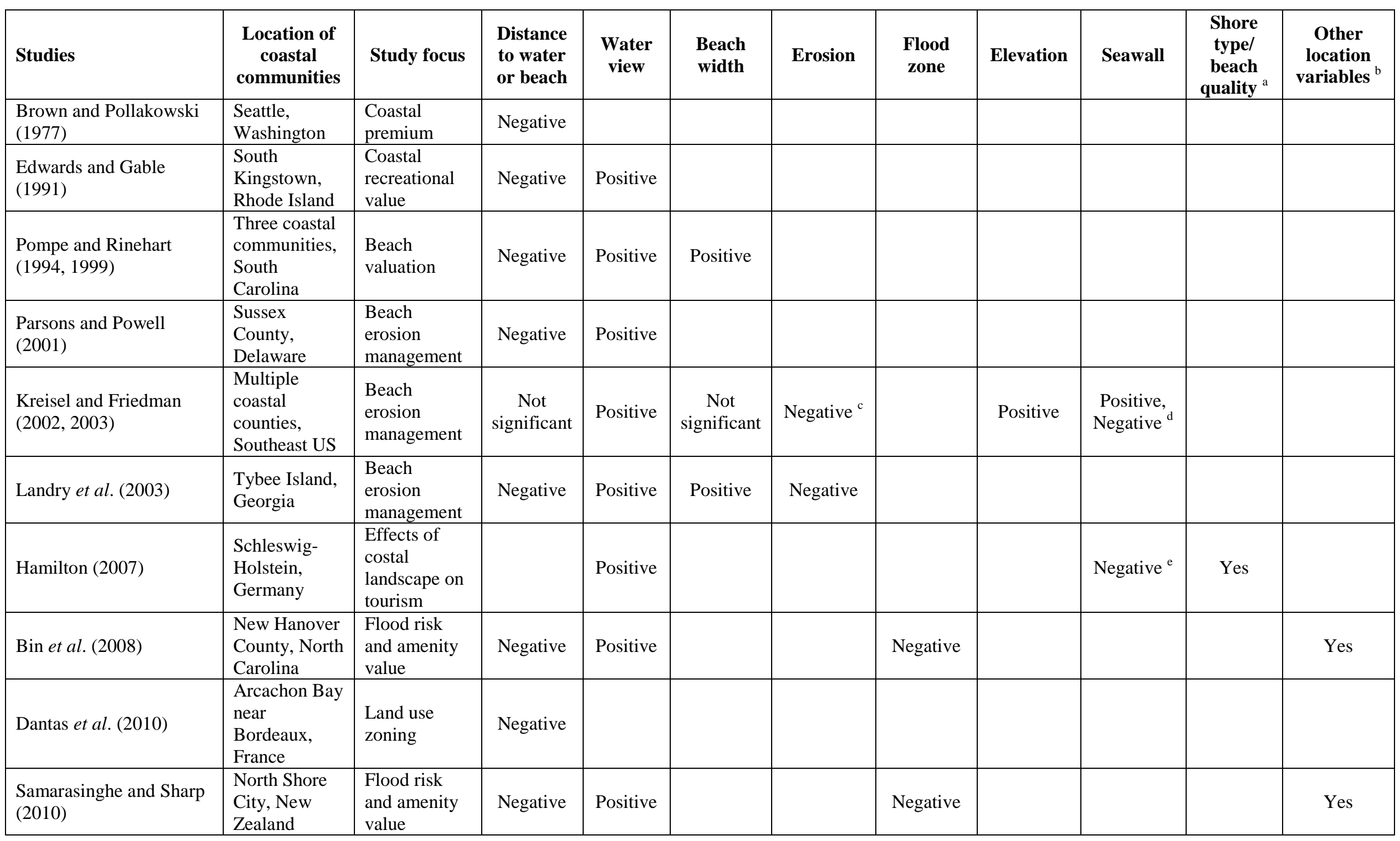




\begin{tabular}{|c|c|c|c|c|c|c|c|c|c|c|c|}
\hline $\begin{array}{l}\text { Eberbach and Hoagland } \\
\text { (2011) }\end{array}$ & \begin{tabular}{|l|} 
Sandwich, \\
Massachusetts
\end{tabular} & Erosion risk & Negative & & Positive & Negative $^{c}$ & \begin{tabular}{c|} 
Not \\
significant
\end{tabular} & & Positive $^{f}$ & & \\
\hline Bin et al. (2011) & $\begin{array}{l}\text { Four coastal } \\
\text { counties, } \\
\text { North } \\
\text { Carolina } \\
\end{array}$ & $\begin{array}{l}\text { Impact of sea } \\
\text { level rise }\end{array}$ & Negative & Positive & & & & $\begin{array}{c}\text { Not } \\
\text { significant }\end{array}$ & & & \\
\hline $\begin{array}{l}\text { Gopalakrishnan et al. } \\
\text { (2011) }\end{array}$ & $\begin{array}{l}\text { Three coastal } \\
\text { counties, } \\
\text { North } \\
\text { Carolina }\end{array}$ & $\begin{array}{l}\text { Beach } \\
\text { erosion } \\
\text { management }\end{array}$ & Negative & & & & & & & Yes & \\
\hline $\begin{array}{l}\text { Landry and Hindsley } \\
\text { (2011) }\end{array}$ & $\begin{array}{l}\text { Tybee Island, } \\
\text { Georgia }\end{array}$ & $\begin{array}{l}\text { Beach } \\
\text { erosion } \\
\text { management }\end{array}$ & Negative & Positive & Positive & $\begin{array}{c}\text { Not } \\
\text { significant }\end{array}$ & & & & Yes & \\
\hline $\begin{array}{l}\text { Conroy and Milosch } \\
\text { (2011) }\end{array}$ & $\begin{array}{l}\text { San Diego } \\
\text { County, } \\
\text { California }\end{array}$ & $\begin{array}{l}\text { Coastal } \\
\text { premium }\end{array}$ & Negative & & & & & & & & Yes \\
\hline $\begin{array}{l}\text { Atreya and Czajkowski } \\
\text { (2014) }\end{array}$ & $\begin{array}{l}\text { Galveston } \\
\text { County, } \\
\text { Texas }\end{array}$ & $\begin{array}{l}\text { Flood risk } \\
\text { and amenity } \\
\text { value }\end{array}$ & Negative & & & & Positive & & Positive & & Yes \\
\hline Landry and Allen 2014 & $\begin{array}{l}\text { Dare County, } \\
\text { North } \\
\text { Carolina }\end{array}$ & $\begin{array}{l}\text { Beach } \\
\text { erosion } \\
\text { management }\end{array}$ & Negative & Positive & Positive & & & & & & \\
\hline
\end{tabular}

a. Variables capture the effects of open coastline, cliff coast, marsh, scarps, sand dunes, and shells on beach.

b. Variables capture the effects of location relative to schools, parks, downtown, and railroads.

c. Variable defined as the expected number of years until the buffering distance between a property and water is zero, given the property's historical erosion rate.

d. Seawall had a positive impact on the values of waterfront homes but a negative impact on homes situated a few rows inland.

e. Dependent variable is the average price of tourist accommodation.

f. Variable captures the effects of a dune reconstructed as a type of "soft" structural protection. 
Table 2. Basic Socioeconomic Information for the Study Area

\begin{tabular}{lccccc}
\hline Town & Population & $\begin{array}{c}\text { Number of } \\
\text { households }\end{array}$ & $\begin{array}{c}\text { Per } \\
\text { capita } \\
\text { income }\end{array}$ & $\begin{array}{c}\text { Median } \\
\text { household } \\
\text { income }\end{array}$ & $\begin{array}{c}\text { Distance to } \\
\text { Boston } \\
(\mathrm{km})\end{array}$ \\
\hline Duxbury & 15,126 & 5,413 & $\$ 54,596$ & $\$ 118,272$ & 56.80 \\
Marshfield & 25,307 & 9,663 & $\$ 43,291$ & $\$ 92,555$ & 50.04 \\
Plymouth & 56,965 & 21,658 & $\$ 35,369$ & $\$ 76,565$ & 65.16 \\
\hline
\end{tabular}

Source: U.S. Census Bureau. 2014. 2009-2013 American Community Survey 5-Year Estimates. 
Table 3. Variable Definitions and Descriptive Statistics

\begin{tabular}{|c|c|c|c|c|c|}
\hline Variable & Measurement & Mean & Std Dev & Min & Max \\
\hline \multicolumn{6}{|l|}{ Price } \\
\hline Price & 2013 dollar & 451,795 & 276,893 & 11,117 & $4,929,951$ \\
\hline $\ln ($ Price $)$ & & 12.890 & 0.517 & 9.316 & 15.411 \\
\hline \multicolumn{6}{|l|}{ Town } \\
\hline Duxbury & Dummy & 0.1384 & 0.3454 & 0 & 1 \\
\hline Marshfield & Dummy & 0.2360 & 0.4247 & 0 & 1 \\
\hline Plymouth & Dummy & 0.6256 & 0.4840 & 0 & 1 \\
\hline \multicolumn{6}{|l|}{ Property Characteristics } \\
\hline Lot size & $10^{-4} \mathrm{~m}^{2}$ & 0.2928 & 0.3632 & 0.0121 & 6.0217 \\
\hline Lot size squared & & 0.2177 & 1.2159 & 0.0001 & 36.2612 \\
\hline Living area & $10^{-3} \mathrm{~m}^{2}$ & 0.1784 & 0.0809 & 0.0390 & 0.6025 \\
\hline Living area squared & & 0.0384 & 0.0376 & 0.0015 & 0.3630 \\
\hline Total rooms & Number & 6.8037 & 1.7177 & 2 & 16 \\
\hline Bedrooms & Number & 3.1582 & 0.8190 & 1 & 7 \\
\hline Bathrooms & Number & 1.9789 & 0.8109 & 0.5 & 7 \\
\hline Age & 10 year & 3.6798 & 3.7056 & 0 & 36 \\
\hline Colonial & Dummy & 0.2693 & 0.4436 & 0 & 1 \\
\hline Cape Cod & Dummy & 0.1772 & 0.3819 & 0 & 1 \\
\hline Ranch & Dummy & 0.1446 & 0.3518 & 0 & 1 \\
\hline Raised ranch & Dummy & 0.0753 & 0.2639 & 0 & 1 \\
\hline Contemporary & Dummy & 0.0701 & 0.2553 & 0 & 1 \\
\hline Bungalow/Cottage & Dummy & 0.0365 & 0.1876 & 0 & 1 \\
\hline Gambrel & Dummy & 0.0485 & 0.2149 & 0 & 1 \\
\hline Garrison & Dummy & 0.0523 & 0.2227 & 0 & 1 \\
\hline Convent & Dummy & 0.0270 & 0.1622 & 0 & 1 \\
\hline Cottage & Dummy & 0.0268 & 0.1615 & 0 & 1 \\
\hline Split level & Dummy & 0.0253 & 0.1570 & 0 & 1 \\
\hline Old style & Dummy & 0.0210 & 0.1435 & 0 & 1 \\
\hline \multicolumn{6}{|l|}{ Location } \\
\hline Elevation & $\mathrm{m}$ & 24.6414 & 15.9067 & 0 & 87 \\
\hline Elevation squared & & 860.158 & 1001.680 & 0.000 & 7569.000 \\
\hline Distance to sea & $\mathrm{km}$ & 2.7716 & 2.2985 & 0.0083 & 9.3769 \\
\hline Distance to water & $\mathrm{km}$ & 2.1444 & 1.9630 & 0.0083 & 8.5957 \\
\hline Square root of distance to water & & 1.2936 & 0.6864 & 0.0909 & 2.9318 \\
\hline Erosion & $\mathrm{km}$ & -0.5092 & 0.9848 & -6.1281 & 0.0598 \\
\hline Close to water (within $50 \mathrm{~m}$ ) & Dummy & 0.0045 & 0.0670 & 0 & 1 \\
\hline Elevation squared ${ }^{*}$ Close to water & & 0.0756 & 1.6517 & 0 & 49 \\
\hline Erosion*Close to water & & -0.0016 & 0.0617 & -3.7193 & 0.0344 \\
\hline \multicolumn{6}{|l|}{ Seawall } \\
\hline Public seawall & Dummy & 0.0641 & 0.2449 & 0 & 1 \\
\hline Private seawall & Dummy & 0.0536 & 0.2252 & 0 & 1 \\
\hline Seawall & Dummy & 0.1176 & 0.3222 & 0 & 1 \\
\hline
\end{tabular}


Shoreline Type

Marsh*Close to water

Dummy

Scarp*Close to water

Dummy

Dummy

Man*Close to water

Dummy

Gravel*Close to water

Dummy

Dummy

Dummy

Dummy

Dummy

0.0018

0.0418

$0.0000 \quad 0.0000$

$0.0025 \quad 0.0500$

$0.0003 \quad 0.0158$

$0.0000 \quad 0.0000$

0

Flood Zone

A

$\mathrm{AE}$

AO

VE

Year

2000

Dummy

Dummy

Dummy

Dummy

$\begin{array}{ll}0.0085 & 0.0919\end{array}$

0.0288

0.1672

0.0110

0.1044

$0.0045 \quad 0.0670$

$\begin{array}{ll}0 & 1 \\ 0 & 0 \\ 0 & 1 \\ 0 & 1 \\ 0 & 0\end{array}$

2001

2002

2003

Dummy

Dummy

0.0130

0.1133

0.0243

0.1539

0.0460

0.2096

0.0838

0.2772

0.0978

0.2971

2005

Dummy

0.1349

0.3416

$0.1109 \quad 0.3140$

Dummy

0.1219

0.3272

Dummy

0.1219

0.2995

2008

2009

Dummy

0.0996

0.3763

0.1707

0.2961

Dummy

0.0971

\begin{tabular}{ll}
0 & 1 \\
0 & 1 \\
0 & 1 \\
0 & 1 \\
& \\
0 & 1 \\
0 & 1 \\
0 & 1 \\
0 & 1 \\
0 & 1 \\
0 & 1 \\
0 & 1 \\
0 & 1 \\
0 & 1 \\
0 & 1 \\
0 & 1 \\
\hline
\end{tabular}


Table 4. Hedonic Equation Estimates

\begin{tabular}{|c|c|c|c|c|c|c|}
\hline \multirow[b]{2}{*}{ Explanatory Variable } & \multicolumn{2}{|c|}{ Model I } & \multicolumn{2}{|c|}{ Model II } & \multicolumn{2}{|c|}{ Model III } \\
\hline & Coefficient & t-value & Coefficient & z-value & Coefficient & z-value \\
\hline \multicolumn{7}{|l|}{ Town } \\
\hline Duxbury & $0.214^{* * *}$ & 10.16 & $0.142^{* * *}$ & 6.80 & $0.248^{* * *}$ & 8.98 \\
\hline Plymouth & $-0.200^{* * *}$ & -13.09 & $-0.149^{* * *}$ & -9.63 & $-0.191^{* * *}$ & -8.79 \\
\hline \multicolumn{7}{|l|}{ Property Characteristics } \\
\hline Lot size & $0.158^{* * *}$ & 4.10 & $0.116^{* * *}$ & 3.79 & $0.165^{* * *}$ & 5.11 \\
\hline Lot size squared & $-0.027^{* * *}$ & -2.61 & $-0.018^{* *}$ & -2.11 & $-0.028^{* * *}$ & -3.19 \\
\hline Living area & $3.542^{* * *}$ & 10.33 & $3.214^{* * *}$ & 10.71 & $3.403^{* * *}$ & 11.23 \\
\hline Living area squared & $-2.173^{* * *}$ & -3.07 & $-1.908^{* * *}$ & -3.41 & $-2.226^{* * *}$ & -3.92 \\
\hline Bathrooms & $0.081^{* * *}$ & 5.81 & $0.073^{* * *}$ & 6.78 & $0.074^{* * *}$ & 6.78 \\
\hline Age & $-0.004^{* * *}$ & -2.74 & $-0.005^{* * *}$ & -3.40 & $-0.007^{* * *}$ & -4.16 \\
\hline Ranch & $-0.045^{* *}$ & -2.34 & $-0.041^{* *}$ & -2.39 & $-0.041^{* *}$ & -2.39 \\
\hline Raised ranch & $-0.062^{* *}$ & -2.38 & $-0.064^{* * *}$ & -3.08 & $-0.071^{* * *}$ & -3.32 \\
\hline Contemporary & $0.074^{* * *}$ & 3.26 & $0.039^{*}$ & 1.74 & $0.060^{* *}$ & 2.38 \\
\hline Bungalow/Cottage & $-0.155^{* * *}$ & -4.47 & $-0.145^{* * *}$ & -4.64 & $-0.153^{* * *}$ & -4.77 \\
\hline Cottage & $-0.151^{* * *}$ & -3.31 & $-0.140^{* * *}$ & -3.81 & $-0.136^{* * *}$ & -3.62 \\
\hline \multicolumn{7}{|l|}{ Location } \\
\hline Distance to sea & $-0.010^{* * *}$ & -3.25 & -0.005 & -1.41 & $-0.010^{*}$ & -1.81 \\
\hline $\begin{array}{l}\text { Square root of distance to } \\
\text { water }\end{array}$ & $-0.026^{* *}$ & -2.05 & $-0.037^{* * *}$ & -2.87 & $-0.038^{* *}$ & -1.99 \\
\hline $\begin{array}{l}\text { Elevation squared*Close to } \\
\text { water }\end{array}$ & $0.011^{* * *}$ & 4.95 & $0.010^{* * *}$ & 3.01 & $0.010^{* * *}$ & 3.16 \\
\hline Erosion $*$ Close to water & $-0.189^{* * *}$ & -4.47 & $-0.161^{*}$ & -1.89 & $-0.172^{* *}$ & -2.02 \\
\hline \multicolumn{7}{|l|}{ Seawall } \\
\hline Seawall & $0.100^{* * *}$ & 4.55 & $0.093^{* * *}$ & 4.98 & $0.078^{* * *}$ & 3.42 \\
\hline \multicolumn{7}{|l|}{ Shoreline Type } \\
\hline Gravel*Close to water & $0.978^{* * *}$ & 12.62 & $0.857^{* *}$ & 2.52 & $0.774^{* *}$ & 2.28 \\
\hline \multicolumn{7}{|l|}{ Flood Zone } \\
\hline $\mathrm{AE}$ & $-0.061^{*}$ & -1.71 & -0.039 & -1.16 & -0.059 & -1.61 \\
\hline \multicolumn{7}{|l|}{ Year } \\
\hline 2000 & $-0.204^{* * *}$ & -3.25 & $-0.223^{* * *}$ & -4.76 & $-0.224^{* * *}$ & -4.78 \\
\hline 2001 & $-0.073^{*}$ & -1.71 & $-0.062^{*}$ & -1.77 & $-0.063^{*}$ & -1.79 \\
\hline 2002 & $0.081^{* * *}$ & 2.64 & $0.082^{* * *}$ & 3.10 & $0.074^{* * *}$ & 2.80 \\
\hline 2003 & $0.222^{* * *}$ & 10.97 & $0.220^{* * * *}$ & 10.64 & $0.219^{* * *}$ & 10.59 \\
\hline 2004 & $0.320^{* * *}$ & 20.55 & $0.316^{* * *}$ & 16.22 & $0.318^{* * *}$ & 16.27 \\
\hline 2005 & $0.339^{* * *}$ & 21.49 & $0.336^{* * * *}$ & 19.30 & $0.338^{* * *}$ & 19.43 \\
\hline 2006 & $0.259^{* * *}$ & 12.12 & $0.255^{* * *}$ & 13.68 & $0.253^{* * *}$ & 13.58 \\
\hline 2007 & $0.179^{* * *}$ & 10.48 & $0.175^{* * *}$ & 9.74 & $0.175^{* * *}$ & 9.75 \\
\hline 2008 & $0.043^{* *}$ & 2.07 & $0.039^{* *}$ & 2.02 & $0.039^{* *}$ & 2.02 \\
\hline Intercept & $12.168^{* * *}$ & 279.08 & $8.974^{* * *}$ & 27.02 & $12.225^{* * *}$ & 292.64 \\
\hline$\rho$ & & & $0.254^{* * *}$ & 9.78 & & \\
\hline$\lambda$ & & & & & $0.364^{* * *}$ & 8.97 \\
\hline$R^{2}$ & 0.58 & & 0.60 & & 0.60 & \\
\hline
\end{tabular}

$*, * *$, and $* * *$ denote significance at $10,5,1 \%$ significance levels, respectively.

Model I: Generalized linear regression model using a White heteroscedasticity-consistent estimator.

Model II: Spatial lag model - maximum likelihood estimation.

Model III: Spatial error model - maximum likelihood estimation. 


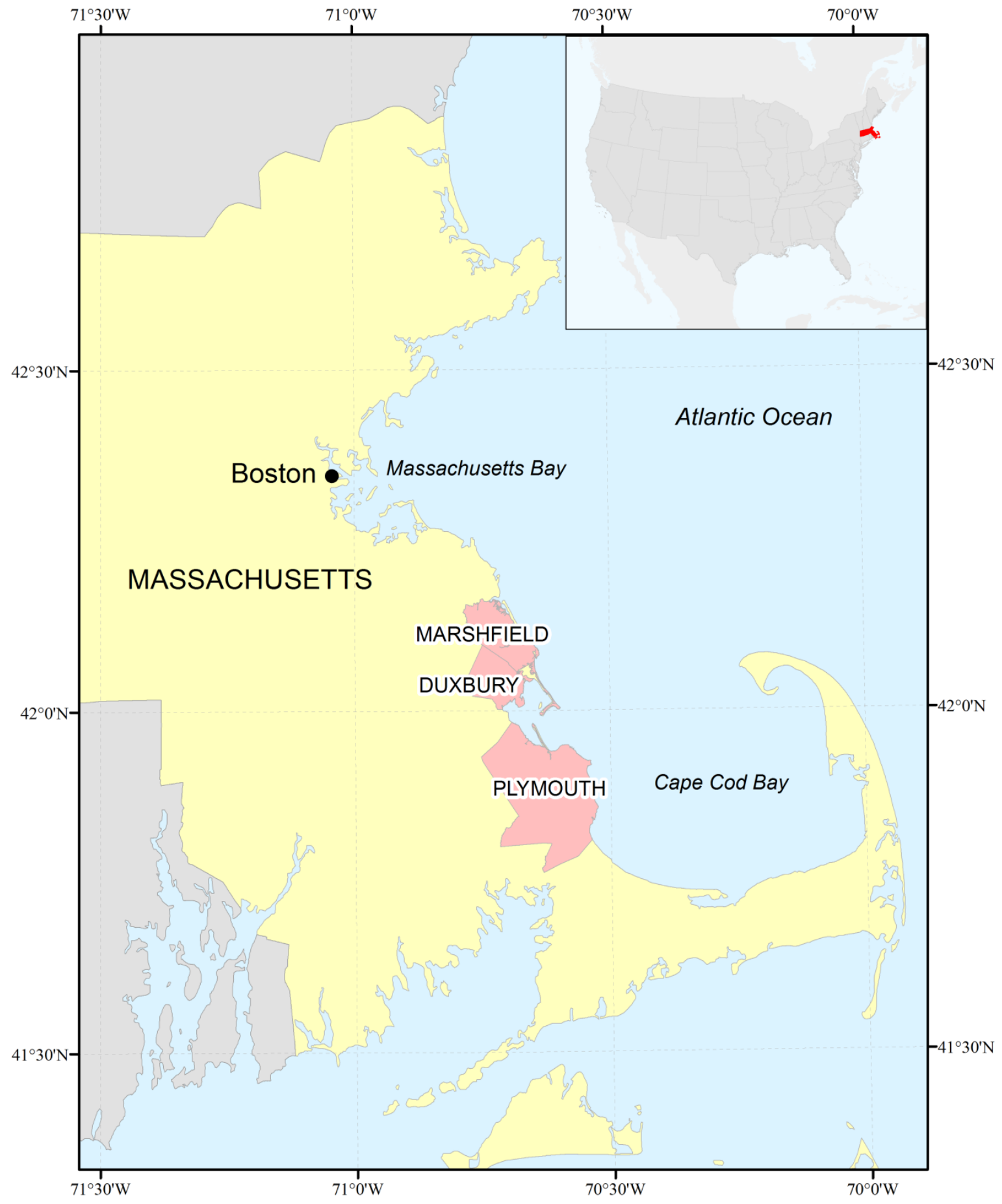

Fig. 1: Location of the study area. 


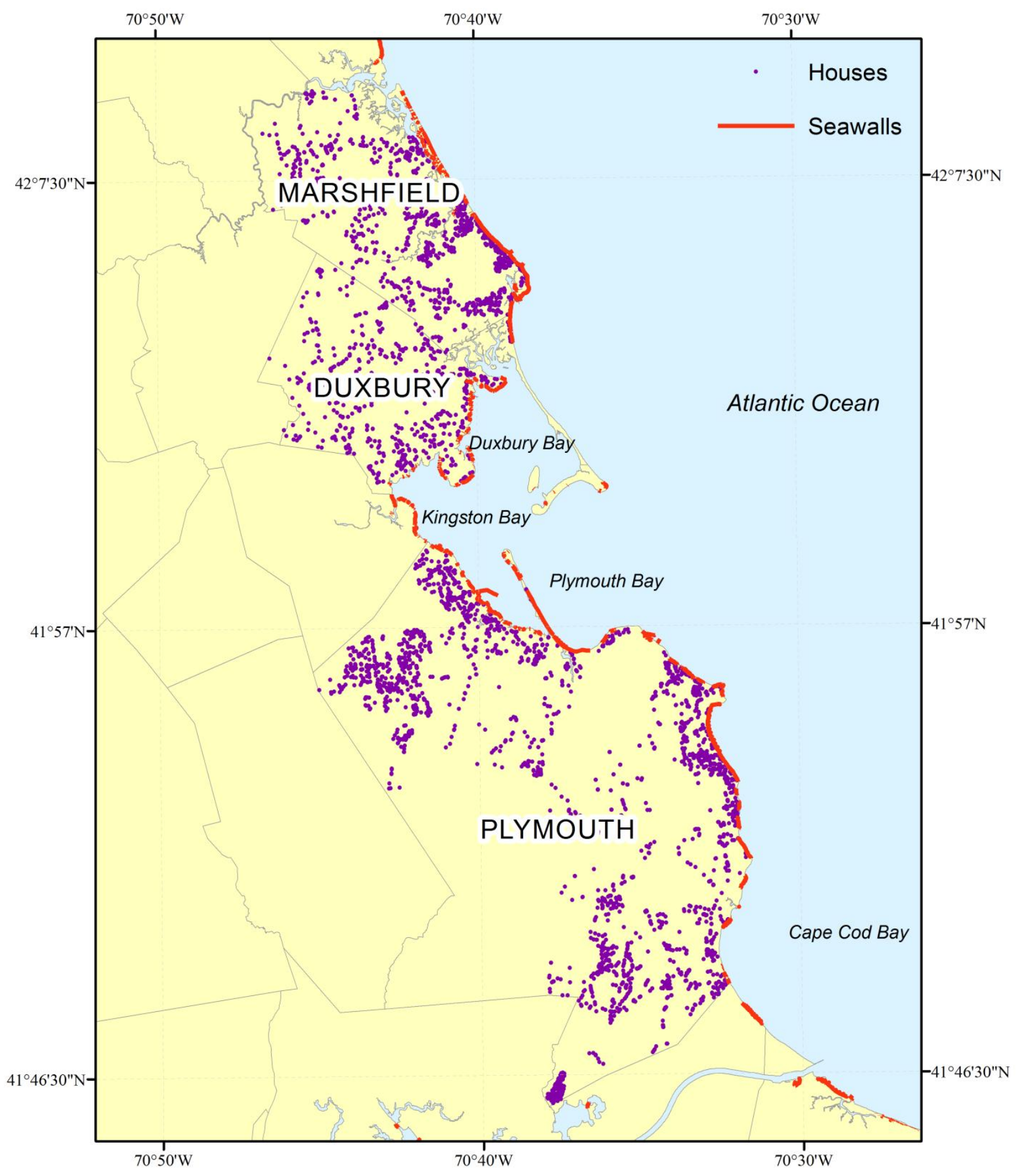

Fig. 2: Locations of residential properties and seawalls in Marshfield, Duxbury, and Plymouth, Massachusetts. 